УдК 378

DOI 10.37386/2413-4481-2020-4-19-23

В.П. Шалаев

Поволжский государственный технологический университет, г. Йошкар-Ола, Россия

ТРАНСФОРМАЦИЯ ВЫСШЕЙ ШКОЛЫ

В ГЛОБАЛЬНОМ ОБЩЕСТВЕ ПОТРЕБЛЕНИЯ

КАК ПРОБЛЕМА НАЦИОНАЛЬНОЙ БЕЗОПАСНОСТИ И УСТОЙЧИВОГО РАЗВИТИЯ

\begin{abstract}
В статье с критических позиций анализируются феномены глобализации и общества потребления как доминанты развития современной истории, рассмотрены сущность общества потребления, под которым автор понимает симбиоз мирового по своим масштабам массового производства товаров и услуг и столь же масштабного массового потребления. В статье критически рассмотрены социальные последствия западного проекта глобализации и общества потребления, их влияние на развитие современного человека и общества, в том числе на сферу образования и высшую школу в частности. Автор приходит к выводу, что современная высшая школа (университетское образование) под влиянием западного проекта глобализации и общества потребления превратилась в фабрики по производству массовой образованной рабочей силы и столь же массового усредненно образованного потребителя, с унифицированными потребностями и подвластным внешним манипуляциям сознанием.

Ключевые слова: глобализация, общество потребления, глобальное производство, глобальное потребление, массовое сознание, трансформация высшей школы, университеты как фабрики массового человека.
\end{abstract}

V.P. Shalaev

Volga State University of Technology, Yoshkar-Ola, Russia

\title{
TRANSFORMATION OF HIGHER EDUCATION IN A GLOBAL CONSUMER SOCIETY AS A PROBLEM OF NATIONAL SECURITY AND SUSTAINABLE DEVELOPMENT
}

The article critically analyzes the phenomena of globalization and consumer society as dominants in the development of modern history. The article examines the essence of a consumer society, by which the author understands the symbiosis of the world-wide mass production of goods and services, and equally large-scale mass consumption. The article critically examines the social consequences of the Western project of globalization and the consumer society, their impact on the development of modern man and society, including the education sector, and higher education in particular. The author comes to the conclusion that modern higher school (university education), under the influence of the Western project of globalization and consumer society, has turned into factories for the production of a mass educated labor force and an equally massive average educated consumer, with unified needs and consciousness subject to external manipulations.

Key words: globalization, consumer society, global production, global consumption, mass consciousness, transformation of higher education, universities as factories of a mass person

\begin{abstract}
Первым тезисом нашего анализа станет утверждение того, что глобализация в ее нынешней форме является своеобразным Левиафаном (пожирающим человека и общество чудовищем) глобального производства и глобального потребления, противоречивая, разрушительная роль которого для человека и общества очень близка образу «Герники» П. Пикассо. Как известно, «Герника» была написана великим художником в 1937 году и исполнена в манере кубизма, в черно-белой
\end{abstract}

гамме, как художественное воплощение разрушительных последствий гражданской войны в Испании (1931-1939 годов).

«Герника» и «Левиафан» (Т. Гоббс) западной формы глобализации и связанного с ней общества потребления - это наша констатация противоречивости и невосполнимости разрушительных последствий, которые они принесли для культуры и цивилизации, сложившихся во всей предыдущей человеческой истории и игравших важнейшую 
организующую, поддерживающую и развивающую роль в жизни человека и общества. Тезисно приведем важнейшие, на наш взгляд, свойства западной глобализации и общества потребления.

Понятие западной глобализация (Globalization) невозможно без понимания ее геополитического значения в современном мире. В XX веке осуществлены два проекта глобализации: западный и советский. Западная глобализация и общество потребления характеризуются как глобальная экономическая колонизация мира: борьба за природные и человеческие ресурсы и рынки сбыта, подчинение западным интересам (западному капиталу и политике) природных, человеческих ресурсов иных стран и народов [1-3].

Западная глобализация и общество потребления являются глобальной культурной колонизаиией мира. Происходит культурная деидентификация народов, замена традиционных национальных и этнических культур на вне- и над-национальные глобальные идентичности. Западная культурная колонизация выступает условием создания управляемой массовой рабочей силы (армия труда) и массового потребителя (армия потребления) [1-4].

Западная глобализация и общество потребления выступают предпосылкой глобального соииального разрушения мира. Прежде всего, воздействие направлено на факторы национальной самоорганизации и безопасности общества: традиционные социальные институты, традиционную мораль, религию, традиционные формы семьи и брака, национальную историческую память и т. д.

Западная глобализация и общество потребления проявляются в тенденциях демократизации и либерализачии, как «мягкая» сила (softpower, англ.) деидентификации и диффузии традиционных культур и идентичностей и фактор западофикации (расширение подчинения стран и народов глобальному обществу потребления).

Западная глобализация и общество потребления характеризуются симбиозом глобального производства (общество всеобщего труда - society ofgeneral work, англ.) и глобального потребления (общество потребления - consumer society, англ.). Это единство - важнейшее условие глобальной экономики и глобальной прибыли.

Западная глобализация, образно выражаясь, является глобальным социальным хищником, Левиафаном современного общества и человека (Т. Гоббс). Глобальное производство и глобальное потребление предполагает агрессивные формы потребления природы, человека и культуры как ингредиентов развития капитала и бизнеса.
Западная глобализация и общество потребления являются предпосылкой, катализатором гистолиза (ускорения) общественного развития, при котором одновременно возрастают риски социальной энтропии (социальной дезорганизации) и социально-природных бифуркаций (катастроф).

Западная глобализация и общество потребления спровоцировали цивилизационную индукиию развития. «Не запад» быстро научился у Запада рациональности и ускоряется в своем развитии. Нарастает конкуренция и борьба за человеческие и природные ресурсы новых глобальных аттракторов (Китай, Индия, мусульманский мир, африканский мир, латиноамериканский мир, евразийский проект России) $[3,4]$.

Западная глобализация и общество потребления предполагают двойную эксплуатацию человека и общества со стороны капитала. Двойное отчуждение человека проявляется, во-первых, в эксплуатации человека как массовой рабочей силы, во-вторых, в эксплуатации человека как массового потребителя. При этом функции науки и образования существенно деформируются, они становятся инструментами глобального производства и глобального потребления, фабриками по производству лояльной массовой рабочей силы и лояльного массового потребителя.

Глобальное производство и глобальное потребление задали новые качества социального лидера. Новые лидеры энергичны, прагматичны, эгоистичны (нарцисстичны). С другой стороны, западная глобализация и общество потребления сопровождаются ослаблением креативности, развитием протестных субкультур и бегством личности от западной цивилизации (дауншифтингом). В этих условиях нарастает потребность в новых духовно ориентированных лидерах, способных на альтруизм, справедливость, ответственность и служение обществу. Мир, обогащенный опытом западной глобализации и общества потребления, находится в ожидании нового мировоззрения, новой идеологии, основанной на духовной морали, ответственности, справедливости и альтруизме [2].

Рассмотрим, что произошло и происходит с университетским образованием под влиянием названных характеристик западной глобализации и общества потребления.

Как нам представляется, прежде всего, следует зафиксировать реализованную логику развития мирового образования от классической консервативной прусской системы (сквозные предметы на всем протяжении обучения, принципы всесто- 
ронности и фундаментальности образования) к либеральной англо-американской системе (выборность предметов, индивидуальные образовательные траектории, дефундаментализация образования). Вершиной этих процессов в Европе можно считать идущий Болонский процесс, уже подвергшийся резкой критике.

В основе этих процессов лежит институциональная деформация развития общества. Происходит качественная трансформация от традиционных социальных институтов, в центре которых интересы общества как интересы личности, к новым либеральным социальным институтам, в центре которых интересы личности как интересы общества. Происходит переход от традиционных форм институционального развития (традиционные семья, религия, мораль, духовные ценности, служение идеалам, кровное родство, коллективизм, свободное творчество, альтруизм, служение, общественный долг, героизм во имя общего блага) к новым либеральным формам социальных институтов (новая либеральная семья, новая религия и мораль как инструменты личности, абстрактный индивид, свобода личности, индивидуализм, материальное потребление, купленный труд, оплаченный креатив, прагматизм, деньги, успех) [2, 4].

Близка к содержанию этих процессов и логика развития философской мысли. Происходит цивилизационный сдвиг актуальной повестки философской мысли от проблематики общества как высшей ценности к темам личности, индивидуальности как высшей ценности общества. Динамика философской мысли легко прослеживается: от Платона (учение об «идеальном государстве»), Т. Кампанелло («город Солнца»), Т. Мора («остров Утопия»), К. Маркса (идеи коммунизма), А. Грамши («Тюремные тетради»), Л. Мэмфорда («Мегамашина»), Э. Фромма («Бегство от свободы»), к идеям Аристотеля, Макиавелли, Ж.-Ж. Руссо, К. Поппера («Открытое общество»), экзистенциализму Ж.-П. Сартра и А. Камю, психоанализу 3. Фрейда и К.Г. Юнга, Г. Маркузе («Одномерный человек»), Ж. Эллюля («Общество всеобщего опосредования»), Ж. Бодрийяра (постмодернизм, «Общество потребления») [5].

Влияние этих институциональных и духовных процессов, сформированных стремлением к западной глобализации и обществу потребления, на современное высшее образование выражается, на наш взгляд, в следующих тенденциях $[1,2]$ :

- дефундаментализация образования (вымывание фундаментальной компоненты образования);

- прикладнизация (ориентация на прикладные профессиональные знания и навыки);
- технологизация (направленность на конструирование искусственной реальности в сфере образования: информатизация, виртуализация, кейсовый дистантизм);

- дегуманизация образования (человек как объект образования выпал из учебного процесса, учебный процесс теперь не ради человека, а ради формально зафиксированных компетенций);

- деэтизация и прагматизация образования (концептуально выражено в идее «хорошо и истинно то, что полезно» («По ту сторону добра и зла», «Сумерки богов» Ф. Ницше);

- индивидуализация образования (построение индивидуальных траекторий в образовании на основе личных предпочтений, конъюнктуры, майнстрима, а не глубинных интересов человека и общества);

- специализированность образования (узкие по охвату знаний профили и программы образования, мелкотемье в подготовке квалифицированного специалиста);

- коммерционализация образования (параметры оценки вузов по совокупному экономическому доходу вуза от бюджета и внебюджета, нацеленность на быстрый практический эффект и финансовый результат как высший критерий эффективности);

- дистанцированность образования от реальной экономики (либо существенное отставание в преподаваемых знаниях и технологиях, либо чрезмерное внешнее заимствование у Запада);

- сервисизация образования (превращение образования в сферу услуг, а преподавателя в наемную обслуживающую рабочую силу);

- потребительство и нарциссизм, эгоизация студенчества (гипертрофированное самомнение личности, приоритет личных интересов, нацеленность на быстрый успех, личное потребление и благополучие);

- либерализация образовательного процесса (условные переводы, возможность второго года в обучении, чрезмерный рост роли мнения студента о деятельности педагога, содержании и результатах обучения);

- деформации организации процесса обучения (борьба за сохранность массового контингента как показатель успешности вуза, борьба за ставки на кафедрах);

- снижение качества абитуриентов (массовые внебюджетные наборы, рост бюджетных мест в вузы, не связанный с реальными потребностями общества как обесценивание статуса высшего образования);

- искажение основных социальных функций высшего образования (доминирование социаль- 
ной функции государства - занятости молодежи, которое теперь обеспечивает образование; вузы как фабрики по производству массовой исполнительской рабочей силы и развитого потребителя на рынке товаров и услуг);

- деидеологизация образования (уход государственной идеологии из системы воспитания профессиональных кадров);

- «окукливание» научно-педагогических кадров (разрушение системы повышения квалификации кадров высшей школы);

- дефицит и старение научно-педагогических кадров высшей квалификации (резкое сокращение численности аспирантур, диссертационных советов);

- разрушение системы планирования подготовки профессиональных кадров (уход государства из научно и экономически обоснованного планирования подготовки кадров и их распределения в экономику.

Закономерно, что под влиянием названных тенденций существенно деформируется социальное качество подготовки специалистов. С нашей точки зрения, наибольшими по своим разрушительным воздействиям стали следующие последствия внедрения глобализации и общества потребления в современное высшее образование:

- падение фундаментальности в подготовке молодых специалистов, поверхностное владение ими профессиональными знаниями;

- утрата творческих способностей и мотивов у молодых специалистов;

- нарастание потребительских мотивов, неоправданная ориентация выпускников вузов на быстрый карьерный или финансовый результат и успех;

- утрата у выпускников готовности к трудовой повседневности, к труду через преодоление трудностей, через поступательный профессиональный рост;

- тенденция к утрате моральной ответственности выпускников в труде (деэтизация труда);

- утрата общественно ориентированной системы ценностей в сознании молодых специалистов (нарциссизм, карьеризм, потребительство, смысловой пауперизм, «нищета философии»);

- неготовность молодых специалистов к крупным начинаниям, ведению крупных дел, управлению коллективами людей (менеджеры, но не организаторы, должностные лица, но не деятели и не общественные лидеры);

- утрата общественного типа человека (общественно ориентированного в своих ценностях и интересах, служителя обществу в профессии и управлении людьми);
- формализация молодых лидеров (ориентация на формальные правила и нормы, но не на практическую деятельность);

- конъюнктурность социальной активности молодых специалистов (волонтерство, общественная работа как способ достижения личных благ);

- уход образованной молодежи в виртуальное пространство (психологическая компенсация неудовлетворенности реальной жизнью.

Наряду с этим следует выделить и наметившиеся положительные тенденции в динамике общественных потребностей в сфере высшего образования, ставшие реакцией на негативные последствия глобализации и общества потребления. К ним мы относим следующие:

- рост экономического запроса общества на специалистов в области фундаментального знания (математики, физики, химики, биологи, качественные учителя-предметники, высококлассные инженеры, врачи);

- рост потребности в общественном типе специалиста, руководителя, деятельность которого основана на ценностях, моральной ответственности, служении и созидании;

- рост потребности различных отраслей экономики в реальных, а не формальных организаторах дела (менеджеры и специалисты по знаниям, умениям и навыкам, а не по факту наличия диплома);

- рост потребности общества в творчески мыслящем и действующем специалисте как антитезе специалисту исполнителю, «ксероксу»;

- рост потребности общества в междисциплинарных специалистах, владеющих смежными профессиями, знаниями и навыками;

- рост потребностей общества в проблемно подготовленных, проблемно ориентированных специалистах, готовых работать в условиях неопределенности, многозадачности;

- наметился процесс переосмысления примитивной цифровизации: растут потребности общества в информационно подготовленных специалистах, где информационные знания и навыки являются дополнительными, а не главными ресурсами образования и профессии;

- рост потребности общества в «мягких» знаниях и технологиях в подготовке специалистов, в специалистах, владеющих социальными и гуманитарными знаниями, играющих важную роль в работе в коллективах и с коллективами.

Таковы лишь основные маркеры развития современного российского высшего образования. Они во многом когерентны процессам на Западе, которые сегодня регистрируются экспертным сообществом. Но сегодня выявленные проблемы, 
скорее, находятся на этапе постановки вопросов, которые надо начинать решать на уровне государства и общества. На наш взгляд, в этом могут помочь технология социальной инженерии, которая заключается в том, чтобы двигаться от понимания, планов и проектов первого, более общего порядка к пониманию, планам и проектам, более конкретным и значимым для обеспечения национальной безопасности России и ее устойчивого развития в быстро меняющемся, все более конкурентном и все более близком к своему экстремуму мире западной оси мировой истории. Нет сомнений в том, что западный формат глобализации кончается, зарождается совсем другой мир. Понять его и означает сохраниться и продлиться в нем. Роль высшего образования в этом деле принципиальная [1].

\section{Библиографический список}

1. Шалаев В. П. Глобализация как западофикация и колонизация мира и эпилог западной оси мировой истории // SocioTime = Социальное время. 2015. № 2. С. 50-59.

2. Шалаев В. П. Осторожно мутация: человек и общество перед вызовами глобализации, западофикации и потребления: противоречия нарастают // SocioTime = Социальное время. 2015. № 3. С. 48-57.

3. Шалаев В. П. Между западофикацией и собственным путем: нелегкий выбор нашего времени (опыт философского анализа) // SocioTime = Социальное время. 2018. № 3 (15). С. 26-36.

4. Петрушков М. Г., Шалаев В. П. Гибридные войны и национальная безопасность Российской Федерации // SocioTime = Социальное время. 2019. № 4 (20). С. 37-47.

5. Шалаев В. П. Человек и общество в глобализированном мире: метаморфозы, вызовы, перспективы. Йошкар-Ола: ПГТУ, 2015. 288 с. 